\title{
The Death of Expertise: The Campaign Against Established Knowledge and Why lt Matters
}

\author{
By Tom Nichols. New York: Oxford University Press;2017
}

\author{
Heejeong Yoo \\ Department of Psychiatry, Seoul National University Bundang Hospital, Seoul National University College of Medicine, Seongnam, Korea
}

Received: August 7, 2018 / Accepted: August 13, 2018

Address for correspondence: Heejeong Yoo, Department of Psychiatry, Seoul National University Bundang Hospital, Seoul National University College of Medicine, 82 Gumi-ro 173beon-gil, Bundang-gu, Seongnam 13620, Korea

Tel: +82-31-787-7436, Fax: +82-31-787-4058, E-mail: hjyoo@snu.ac.kr

Communicating with non-experts is one of the most important activities in my occupation. While performing the same job for many years, my communication style has changed considerably, and lately I have felt the need to adapt more and more rapidly. It is difficult to consider this change entirely intentional. Rather, it is a response to changes in the questions and attitudes of the people who visit me. They already come equipped with more knowledge and want to use that knowledge to engage me in genuine discussion, or to verify, rather than ask, my opinion. This trend has been accompanied by an increase in the proportion of their knowledge that has no clear source or origin. Moreover, starting with "Anarchy" [1], there have been numerous cult-like phenomena that overtly demonstrate the everyday crises faced by experts where false information misleads a large portion of society. Examples include the anti-vaccine movement based on the belief that vaccines cause autism, attempts to invalidate medical diagnoses, such as the previously popular book claiming that "There is no attention-deficit/hyperactivity disorder" [2], and countless trends for alternative medicine or treatments lacking evidence in pediatric psychiatric disease. These matters indicate how people define experts, how they decide whom to trust, and what information to process and put into action. Medicine is fundamentally a branch of science, and these phenomena demonstrate how society interprets data and logic through a subjective, distorted lens.

"The Death of Expertise: The Campaign against Established Knowledge and Why it Matters", by Nichols T [3], shows that these concerns are not only present in specific fields,

This is an Open Access article distributed under the terms of the Creative Commons Attribution Non-Commercial License (https://creativecommons.org/licenses/by-nc/4.0) which permits unrestricted non-commercial use, distribution, and reproduction in any medium, provided the original work is properly cited. such as public healthcare, medicine, and psychiatry. The author is an expert on the issue of Russia and began writing about the crisis of expertise due to an interest and disappointment in the way that, concerning policy issues, the media and policy non-experts conveyed false information to the public, and used this to influence politics and elections. At first, he wrote in a personal blog, followed by a column in "The Federalist" [4] Eventually this content was collated and published as a book. In this book, the author discusses the following as reasons why people no longer respect the opinions of experts and why debate is dominated by 'fake experts': the universal illogicality of humans, who are susceptible to confirmation bias, and believe fictions, superstitions, and conspiracies; the deterioration of education at US colleges, which have become like for-profit groups that only cater to the demands of students and overprotective parents; the resulting reality where "the emotions of the demand-group have become more important than facts or reason"; the lack of discrimination regarding the wealth of information available through the internet; problems with journalism that have given birth to fake experts; issues of mistrust in the media; and experiences of various past incidents in which experts voiced incorrect opinions. In the final chapter, the author suggests somewhat of a solution to how experts and the general public should form relationships.

The author attributes much to the societal changes experienced by the media and college education as the US transitioned from a modern to a contemporary society. This is noticeable because, rather than simply discussing facts, the author also focused on the changes in value systems and group psychology experienced by society. The author criticizes simply listing information from the Internet as "the cheapened sense of equality it provides, is corroding trust and 
respect among all of us, experts and laypeople alike (Chapter 4. Let me google that for you: how unlimited information is making us dumber) [5]. However, as a downside of these technological advances, the author argues that, "one reason claims of expertise grate on people in democracy is that specialization is necessarily exclusive (Chapter 1 . Experts and citizens)" [6] and another reason for "unwillingness to accept expert advice is rooted in the same kind of populist suspicion of those perceived as smarter or more educated than the general public (Chapter 2. How conversation became exhausting)" [7]. In other words, the current situation where experts' opinions are not accepted and anyone can attract the public's interest as if they were an expert, is not only because it was on the cusp of addition of new technologies like cable, but also because "those developments coincided with an accelerating collapse of trust in government and other institutions in American life (Chapter 5. The "new" new journalism, and lots of it)" [8]. In South Korea, the public have a long history of being ruled by a unilateral authority, and have been exposed to massive group trauma, which is fertile soil for conspiracies. In this regard, the recent mistrust and derogation of experts in Korea could be considered a type of transitional chaos state accompanied by rapid growth in demands for equality and equity.

Within such a society, the author seems to have conceived of this book as a means of persuading the public and restoring the authority and influence of experts. He argues that laymen should strive to constantly listen to the words of experts and develop their own curiosity, and to relax their stereotypes and understanding of experts, while experts themselves need to listen to other experts. However, the author also seems to believe that contemporary US society should be considered as being in an "age of mistrust in authority." This will likely be the case in Korea for some time, as can be seen by looking at the recent medical drama (or political drama, posing as a medical drama), "Life." A new CEO comes in to run the hospital and tries to use economics-based logic to reconstruct the framework of the healthcare system, raising questions of whether a hospital should be managed to generate profit, or to serve the public good, whether the CEO should be a medical expert, the scope of doctors' work as experts, and the extent to which administrators should accept the claims of medical experts. In other words, it seems that we are living in a sort of sociopolitical war in which we need to redefine who is setting the agenda, and what authority and equality mean. As described in Yavel Noah Harari's "Homo Deus" [9], in the near-future, humanity may develop into a society where data, rather than the ego of individuals, produces data, and this determines not only the lives of humans and course of societal phenomena, but even ethical standards. Thus, whether we like it or not, it is probable that we will come to live in a society that differs greatly from what we have experienced to date. While working as an expert, I am both sad and angry about the authority of my words being challenged; but I also believe that understanding and adapting to this new paradigm is an important task, not only for one's intangible identity as an individual, but for humanity as a whole.

\section{Conflicts of Interest}

The author has no financial conflicts of interest.

\section{REFERENCES}

1) Lee M. "I'd like to have rubella party with whole nation", Ahn Hyojin, Korean medicine doctor, the founder of 'Anarchy'. Joongang Ilbo [serial online] 2017 May [cited 2018 Aug 15]. Available from URL:https://news.joins.com/article/21609395.

2) Kim GR. ADHD-neun eopda [There is no ADHD]. Seoul: Mindle; 2013.

3) Nichols T. The death of expertise: the campaign against established knowledge and why it matters. New York: Oxford University Press; 2017.

4) Nichols T. The death of expertise. Federalist [serial online] 2014 [cited 2018 Aug 15]. Available from URL:http://thefederalist.com/ 2014/01/ 17/the-death-of-expertise/.

5) Nichols T. Chapter 4. Let me google that for you: how unlimited information is making us dumber. In: Nichols T, editor. The death of expertise: the campaign against established knowledge and why it matters. New York: Oxford University Press;2017. p.132.

6) Nichols T. Chapter 1. Experts and citizens. In: Nichols T, editor. The death of expertise: the campaign against established knowledge and why it matters. New York: Oxford University Press;2017. p.61.

7) Nichols T. Chapter 2. How conversation became exhausting. In: Nichols T, editor. The death of expertise: the campaign against established knowledge and why it matters. New York: Oxford University Press;2017. p.61.

8) Nichols T. Chapter 5. The "new" new journalism, and lots of it. In: Nichols T, editor. The death of expertise: the campaign against established knowledge and why it matters. New York: Oxford University Press;2017. p.145.

9) Harari YN. Homo Deus: a brief history of tomorrow. London: Vintage;2017. 